\title{
PENDIDIKAN ISLAM DAN PENYIAPAN BONUS DEMOGRAFI INDONESIA TAHUN 2045
}

\author{
Nailatul Muna \\ e-mail : nailamunaworld27@gmail.com \\ Universitas Islam Negeri Sunan Kalijaga Yogyakarta
}

\begin{abstract}
Abstrak
Bonus Demografi merupakan fenomena kependudukan yang menarik untuk dikaji. Bonus demografi dapat memberikan berkah bagi bangsa Indonesia dan kesempatan besar untuk mengubah masa depan bangsa Indonesia. Bonus demografi merupakan periode emas atau generasi emas untuk mempersiapakan generasi baru dalam memasuki tahun 2045, ketika Indonesia memasuki satu abad kemerdekaannya. Bonus demografi ditandai dengan banyaknya usia produktif dari pada usia non produktif, dengan banyaknya usia produktif ini diharapkan dapat memajukan Indonesia dengan cara mempersiapakan secara matang peluang yang akan muncul ketika fenomena bonus demografi salah satunya melalui sektor pendidikan. Pendidikan pada umumnya dan pendidikan islam pada khususnya mempunyai peranan sangat penting bagi kehidupan umat manusia agar manusia dapat mengarungi kehidupan di dunia dan memperoleh kemenangan yang hakiki. Era bonus demografi diharapkan para generasi muda tidak hanya memiliki kecerdasan dan produktifitas, akan tetapi juga harus memiliki karakter yang kuat. Melalui pendidikan islam diharapkan dapat membangu karater ( Caracter Building) yang membentuk generasi emas menjadi insan beriman, berpengetahuan tinggi, berakhlak mulia, tekun beribadah, berjiwa sosial, dan bertaqwa.
\end{abstract}

Kata Kunci : Bonus Demografi,Pendidikan Islam

\begin{abstract}
The bonus is the phenomenon of population Demographics that are interesting to review. The demographic bonus can give a blessing to the people of Indonesia and a great chance to change the future of the nation of Indonesia. Bonus demographics is golden or golden generation period for preparing the new generation in the year 2045. The year when Indonesia enters a century of independence. Demographic bonus is marked with the number of productive age in the age of non productive, with the number of productive age is expected to advance by way of Indonesia set up in ripe opportunities which will arise when the phenomenon through one demographic bonus education sector. Education education in General and Islamic education in particular have a very important role for the life of humanity so that humans can navigate through life in the world and gained a substantial victory. In an era of demographic bonus expected the younger generation not only have the intelligence and productivity, but must also have a strong character. Through Islamic education is expected to be constructed karater (Caracter Building) that make up the golden generation of the faithful, knowledgeable employees become a high, noble character, diligent worship, social status, and soulless.
\end{abstract}

Keywords: Demographic bonus, Islamic education, Caracter Building 


\section{A. Pendahuluan}

Peran pendidikan dalam membangun peradaban bangsa yang berdasarkan atas jati diri dan karakter bangsa sangatah penting. Pendidikan adalah suatu proses di mana suatu bangsa mempersiapkan generasi mudanya untuk menjalankan kehidupan dan untuk memenuhi tujuan hidup secara efektif dan efisien. Disamping itu pendidikan adalah suatu hal yang benar-benar ditanamkan selain menempa fisik, mental dan moral bagi individu-individu agar mereka menjadi manusia yang berbudaya sehingga diharapkan mampu memenuhi tugasnya sebagai manusia yang diciptakan Tuhan Semesta Alam. Sebagai mahluk yang sempurna dan terpilih sebagai khalifahNya di muka bumi ini yang sekaligus menjadi warga negara yang berarti dan bermanfaat bagi suatu negara.

Indonesia merupakan salah satu negara dengan penduduk terbanyak. Faktor ini bisa menjadikan berkah ataupun musibah bagi bangsa Indonesia, karena dengan banyaknya penduduk Indonesia akan memiliki banyak tenaga kerja yang dapat dijadikan sebagai sumber daya, namun disisi lain besarnya jumlah penduduk membuat tanggungan pemerintah semakin besar terlebih jika penduduk tersebut tidak produktif. Indonesia memiliki tingkat pertumbuhan penduduk yang tinggi pada tahun 1970 yakni2,33\% pertahun, dan berhasil ditekan sehingga pada periode 2010-2014 menjadi 1,4\% per tahun. Pertumbuhan penduduk diperkirakan masih akan berkisar pada angka1,5-0,7 persen pertahun untuk beberapa dekade ke depan. Dalam laporannya, BPS (badan pusat statistik) memproyeksikan jumlah penduduk Indonesia pada 2035 akan mencapai 305,6 juta jiwa (Prastyo:2015).

Sumber Daya Manusia menjadi point penting yang menentukan maju dan mundurnya suatu negara. SDM yang memiliki kualitas baik, dari segi etos kerja, soft skill dan life skill, mumpuni dan dapat berdaya saing akan bisa menggerakkan roda perekonomian suatu negara menuju kearah kemakmuran dan kesejahteraan. Akan tetapi jika sebaliknya kualitas SDM rendah, maka negara akan berada pada ambang kehancuran. Indonesai yang dikarunia SDM lebih dari seperempat milyar memiliki potensi besar untuk menjadi negara besar jika SDMnya benarbenar diberdayakan secara
maksimal.Persaingan di era global seperti sekarang ini sangatlah ketat setiap bangsa dituntut untuk meningkatkan kualitas dan produk sumber daya mausia yang terdidik agar tidak tertinggal begitu jauh dengan negara-negara berkembanglainnya. Maka perlu adanya persiapan sejak dini untuk menghadapi tantangan kedepan.

\section{B. Tujuan Penelitian}

Tujuan yang ini peneliti pakai dalam penelitian ini adalah : Mengetahui Potensi Sumber Daya Alam dan terkhusus lagi sumber daya manusia, sehingga menjadi acuan serta panduan yang valid dalam pengembangan Sumber Daya Manusia dan Sumber Daya Alam yang ada di Indonesia.

\section{Metode Penelitian}

Jenis penel;itian yang digunakan adalah penelitian deskriptif kualitatif dengan cara memberikan gambaran, serta menuturkan dan memberikan tafsiran data yang pada akhirnya menghasilkan data deskriptif yang berbentuk kata-kata tulisan.

Dalam teknik pengumpulan data peneliti melakukan penelusuran data selama penelitian, baik berupa dokumentasi dalam bentuk uraian dalam tulisan yang kemudian peneliti analisa sehingga menjadi hasil kesimpulan.

\section{Pembahasan}

\section{Bonus Demografi}

Indonesia adalah negara berpenduduk terpadat nomor empat didunia, komposisi dengan etnis yang sangat variatif karena negara indoesia Fenomenas bonus demografi atau disebut juga demographic dividend adalah keadaan di mana penduduk usia produktif memiliki jumlah yang jauh lebih banyak daripada penduduk usia non produktif. Berdasarkan sensus penduduk diperkirakan pada tahun 2010 Indonesia akan mengalami ledakan populasi usia produktif dimana jumlah anak usia 0-9 tahun berjumlah 45,93 juta jiwa, sedangkan usia 10-19 tahun berjumlah 43,55 juta. Pada tahun 2045, usia 0-9 tahun akan berusia 35-45 tahun, sedangkan yang ber usia 10-20 tahun berusia 45-54 tahun (Sutrisno \& Suyatno:2015). 
Bonus demografi ditandai dengan banyaknya fertilitas (kelahiran) penduduk sehingga mengakibatkan peningkatan jumlah penduduk yang sangat signifikan pada setiap tahunnya, kemudian pemerintah melakukan upaya-upaya agar tidak terjadi ledakan penduduk. Program KB yang dicanangkan oleh pemerintah menjadi salah satu alternatif untuk mengurangi lonjakan penduduk di Indonesia. Dengan ditekannya jumlah kelahiran, otomatis jumlah penduduk usia muda dari angkatan-angkatan sebelumnya akan melonjak drastis ketimbang angkatan berikutnya. Jumlah penduduk usia muda yang banyak inilah yang kelak akan menjadi angkatan kerja yang disebut dengan istilah bonus demografi. Kenapa disebut bonus? Karena banyaknya penduduk usia produktif maka beban yang di tanggung penduduk usia produktif untuk membiayai penduduk usia non produktif akan lebih sedikit.

Fenomena bonus demografi ini merupakan fenomena sejarah yang sangat jarang terjadi, diproyeksikan tepat satu abad Indonesia merdeka atau tahun 2045 bonus demografi ini terjadi. Indonesia akan mendapatkan manfaat positif jika bonus demografi ini dekelola dengan baik dan tepat. Akan tetapi jika fenomena bonus demografi tidak diantisipasi sejak dini akan menjadi bencana demografi (demografdhic disaster) bagi Indonesia. Jika bangsa Indomesia bisa memanfaatkan dan mempersiapakan isu bonus demografi dengan baik maka akan muncul peluangpeluang yang menguntungkan bagi bangsa Indonesia. Tanpa persiapan yang matan bonus demografi akan menjadi bumerang bagi bangsa Indonesia dan khususnya akan menjadi beban besar bagi pemerintah dan angka pengangguran akan semakin meningkat.

Selain perubahan dalam struktur kependudukan pada saat fenomena bonus demografi, pola pertumbuhan penduduk yang akan terjadi pada masa mendatangpun diperkirakan akan berdeda sama sekali dengan pola pertumbuhan yang terjadi 10 tahun terakhir. Semakin sempurnanya pelayanan kesehatan, pendidikan, peningkatan indeks daya beli dan akan menurunkan tingkat kematian dan kelahiran sehingga terjadilah sebuah transisi demografi (Suryadi:2014). Transisi demografi adalah suatu gejala yang memperlihatkkan susunan penduduk yang makin sempurna yang dapat ditunjukkan dengan pergeseran struktur penduduk dari tingkat fertilitas tinggi dan mortalitas tinggi ke pola perkembangan penduduk yang memiliki tingkat fertilitas rendah dan mortalitas rendah. Transisi demografi seperti ini adalah implikasi dari terjadinya perubahan sikap, perilaku, dan cara hidup sebagian besar penduduk Indonesia yang semakin efisien dan produktif, serta perubahan cara hidup yang semakin modern (Suryadi:2014).

\section{A. Pendidikan Islam}

Pendidikan adalah kegiatan mentransferkan ilmu pengetahuan melalui pendidikan formal, informal atau nonformal, dengan cara mengajarkan, melatih, membimbing, dan mengarahkan peserta didik untuk mencapai tujuan dari pendidikan.Pendidikan memiliki peran yang sangat penting dalam mewujudkan pembangunan masyarakat. Pendidikan diharapkan senantiasa bisa memenuhi kebutuhan dan tantangan masyarakat seiring dengan perkembangan yang ada. Untuk menghadapi tantangan global pendidikan dianggap menjadi sarana terbaik yang didesain dalam menciptakan generasi penerus yang tidak kehilangan ikatan dengan tradisi mereka sendiri akan tetapi juga tidak menjadi bodoh dari segi intelektual atau terbelakang dalam pendidikan. Oleh karena itu pendidikan harus didesain mengikuti alur perubahan.

$$
\text { Pendidikan islam adalah }
$$

pendidikan manusia seutuhnya, akal, dan hatinya, rohani dan jasmaninya, akhlak dan keterampilannya. Karena itu pendidikan islam menyiapkan manuasia untuk hidup baik dalam keadaan damai dan menyiapkan untuk menghadapi masyarakat dengan segala dinamika yang ada (Azra:1998). Sejalan dengan tujuan pendidikan nasional adalah untuk mengembangkan potensi peserta didik agajr menjadi manusia yang beriman dan bertaqwa kepada Tuhan Yang Maha Esa, berakhlak mulia, sehat, berilmu, cakap, kreatif, mandiri, dan menjadi warga negara yang demokratis dan bertanggung jawab. Dituangkan dalam UU Nomor 20 tahun 2003.

Pendidikan islam memiliki tugas pokok yaitu menggali, menganalisis dan mengembangkan serta mengamalkan ajaran islam yang bersumber pad AlQuran dan Al-Hadis, dari kedua sumber tersebut pendidikan islam sudah cukup mendapatkan pedoman dariisi kandungan 
mankna yang terungkap. Makna yang komprehensif dari sumber tersebut dapat menjangkau dan melingkupi segala aspek kehidupan manusia moderen (PRESMA Fak.Tarbiyah UIN SUKA:2004).

Menjadi kesepakatan bersama bahwa pendidikan merupakan point penting dalam perkembangan keberadaban manusia dimuka bumi. Dalam agama islam khususnya, sangat menganjurkan pemeluknya untuk menuntu ilmu, karena menurut pandangan islam pendidikan merupakan kebutuhan hidup yang harus dipenuhi, demi mencapai kesejahteraan dan kebahagiaan dunia dan akhirat. Dengan pendidikan manusia bisa mendapatkan berbagai macam ilmu pengetahuan untuk bekal dalam kehidupannya. Sejalan dengan tujuan pendidikan nasional, pendidikan islam memiliki tujuan untuk membentuk insan kamil, dengan harapan melalui pendidikan islam dapat menghasilkan manusia yang unggul, berguna bagi diri sendiri maupun masyarakat, serta dapat mengamalkan dan mengembangkan ajaran islam sehingga tercapai kebahagiaan dunia dan akhirat.

\section{B. Pendidikan Islam dalam menyongsong Bonus Demografi}

Perubahan dan perkembangan zaman melaju dengan cepat. Beberapa fase-fase dari agrarian ke industri kemudian ke informasi dan yang terakhir ini adalah globalisasi. Perubahanperubahan ini memberikan dampak yang cukup besar bagi masyarakat. Untuk itu perlu adanya persiapan guna menghadapi masa mendatang yang semakin banyak tantangan. Indonesia yang mayoritas penduduknya memeluk agama Islam, memiliki peluang yang sangat strategis guna menyongsong bonus demografi melalui lembaga-lembaga pendidikan Islam. Dapat kita lihat banyak sekali lembaga pendidikan Islam yang ada di negeri ini, selain itu dilihat dari sisi sejarah lembaga pendidikan di Indonesai telah terbukti dapat eksis mengikuti arus zaman dari zaman sebelum merdeka hingga zaman reformasi.

Peran pendidikan disini yaitu
bagaimana proses pendidikan
mengembangkan ilmu pengetahuan dan
keterampilan dengan menanamkan nilai-
nilai demokrasi, keimanan, akhlak,
kemanusiaan, keadilan, hukum, toleransi
solidaritas, untuk membangun dan
memberdayakan manusia dan masyarakat

berkualitas yang memiliki kemampuan inovasi, kreasi, koorporasi, kompetitif, dan menerima perubahan sehingga pendidikan dapat mendatangkan kemaslahatan dalam kehidupan mausia (Sanaky:2003). Gambaran sosok manusia Indonesia generasi 2045 harus menjadi pijakan upaya pendidikan khususnya pendidikan Islam dalam meningkatkan kualitas, oleh karena itu pendidikan Islam perlu mereformasi desain pendidikan yang sesuai dengan kebutuhan dan karakteristik model masyarakat diera bonus demografi.

Untuk menghadapi dan membangun masyarakat di era bonus demografi maka langkah-langkah yang perlu dilakukan pendidikan Islam adalah (1) perlu adanya pemikiran kembali konsep pendidikan Islam yang didasarkan pada asumsi dasar tentang fitrah dan potensi manusia, (2) pendidikan Islam harus dapat mengintegrasikan antara keilmuan umum dan keilmuan agama agar tidak terjadi jurang pemisah antar keduanyan, (3) pendidikan didesain agar tercapainya sikap dan perilaku "toleransi", lapang dada dalam berbagai hal dan bidang, terutama toleransi dalam perbedaan pendapat dan penafsiran ajaran isla, tanpa meninggalkan prinsip-prinsip yang diyakini, (4) pendidikan mampu menumbuhkan kemandirian, etos kerja, disiplin, jujur dan swadaya dalam kehidupan, (5) pendidikan islam perlu didesain untuk menjawab tantangan masyarakat dan lentur terhadap perubahan zaman (Sanaky:2003).

Untuk menciptanya fungsi
lembaga pendidikan Islam yang terintegrasi dalam diri pribadi muslim, maka diperlukan konsep pendidikan yang komprehensif yang dapat mengantarkan pribadi muslim kepada tujuan akhir pendidikan yang ingin dicapai. Permasalahan pokok yang sangat perlu mendapat perhatian adalah penyusunan rancangan program pendidikan yang dijabarkan dengan kurikulum. Berpedoman pada lingkup pendidikan Islam yang ingin dicapai, maka kurikulum pendidikan Islam itu harus berorientasi pada 1). Tercapainya tujuan hablum minallah, 2). Tercapainya tujuan hablum minannas, 3). Terciptanya tujuan hablum minal'alam.Pendidikan isam tidak hanya sekedar mentrasfrmasikan nilai-nilai yang bersifat universa, tetapi juga memberikan makna nilai-nilai tersebut untuk manusia agar berakhak mulia (Prasetya:2015). 


\section{Penutup}

$\begin{array}{rrr}r \text { Pendidikan menjadi sangat penting } \\ \text { guna meghadapi } & \text { perkembangan } \\ \text { keberadaban } & \text { manusia, } & \text { dengan } \\ \text { menyensuaikan } & \text { kebutuhan } & \text { dan }\end{array}$ karakteristik masyarakat pada era bonus demografi. Oleh karena itu, pendidikandi Indonesia perlu berorientasi pada pengembangan ilmu pengetahuan dan teknologi. Khusunya untuk pendidikan islam perlu mempersiapkan dan usaha pembaharuan yaitu terkait dengan setting pendidikan, lingkungan pendidikan dan kurikulum pendidikan yang sesuai dengan kebutuhan.Usaha pembaharuan pendidikan islam tidak akan terwujud apabila tidak memiliki pondasi yang kuat yaitu dengan perlu dirumuskannya visi dan misi pendidikan agar dapat membangun dan meningkatkan kualitas manusia.

Dengan adanya fenomena bonus demografi dan persiapan pendidikan dalam menyonyong berkembangan yang ada diharapkan bisa membaca peluang peluang dan menjadi tombak bagi bangsa Indonesia untuk meningkatkan kesejahteraan dan bisa bersaingan dengan negara-negara maju lainnya.

\section{DAFTAR PUSTAKA}

Azra,Azyumardi. Pendidikan Islam Tradisi dan Modernisasi Menuju Milenium Baru, ( Jakarta: Logos wacana ilmu, 1998).

Prastyo UI, Eka.Meneropong Indonesia 2035, ( Depok : KSM Eka Prastya UI, 2015).

PRESMA Fak.Tarbiyah UIN SUKA, Pendidikan Islam dan Tantangan Globalisasi, (yogyakarta: Ar-Ruzz Media, 2004).

Sanaky,Hujair AH.Paradigma Pendidikan Islam: Membangun Masyarakat Madani Indonesia, (Yogyakarta: Safira Insani Press, 2003).

Suryadi,Ace. Pendidikan Indonesia Menuju 2025, (Bandung :Remaja Rosdakarya, 2014).

Sutrisno \& Suyatno, Pendidikan Islam di Era Peradaban Moderen, ( Jakarta: Prenadamedia Group, 2015). 